\title{
Ganodermataceae (Polyporales): Diversity in Greater Mekong Subregion countries (China, Laos, Myanmar, Thailand and Vietnam)
}

\author{
Hapuarachchi $\mathrm{KK}^{2,3,4}$, Karunarathna $\mathrm{SC}^{5}$, Phengsintham $\mathbf{P}^{6}$, Yang $\mathbf{H D}^{2,7}$, \\ Kakumyan $\mathrm{P}^{4}$, Hyde $\mathrm{KD}^{2,3,4}$, Wen TC ${ }^{1,2}$
}

The above article of Hapuarachchi et al. 2019 has been retracted because of incorrect and incomplete citation in Table 1 as well as one nomenclatural taxonomic confusion.

Article was officially published on 9 April 2019 and has been retracted by the Scientific Editor in Chief, Associate Professor Rajesh Jeewon on 22 April 2019.

A corrected version the article with appropriate changes will be made available for readers shortly.

Hapuarachchi KK, Karunarathna SC, Phengsintham P, Yang HD, Kakumyan P, Hyde KD, Wen TC 2019 - Ganodermataceae (Polyporales): Diversity in Greater Mekong Subregion countries (China, Laos, Myanmar, Thailand and Vietnam). Mycosphere 10(1), 221-316, Doi 10.5943/mycosphere/10/1/4

\begin{abstract}
Taxa of Ganodermataceae have been widely used as traditional medicines for centuries in Asia. Despite several taxonomic investigations, relationships and classification of many species are still unresolved. Species in this family are either pathogenic, wood decaying and/or wood inhabiting. In this paper, we introduce, a collection of Ganodermataceae species based on fresh and dried specimens found within the Greater Mekong Subregion countries; China, Laos, Myanmar, Thailand and Vietnam. Amauroderma schomburgkii, A. rude, Haddowia longipes, Ganoderma lingzhi, G. luteomarginatum, G. subresinosum and G. tropicum from Laos, G. australe and G. multiplicatum from Myanmar, G. donkii from Thailand, G. adspersum from Thailand and Myanmar, G. flexipes, G. gibbosum, G. orbiforme, and G. neojaponicum from both Laos and Myanmar, are newly recorded species for these countries. We also identified A. schomburgkii and A. rude, based on morphology and the other species based on both morphology and DNA sequence data. Two species; G. nasalanense Hapuar., Pheng., \& K.D. Hyde, sp. nov., and G. sandunense Hapuar., T.C. Wen \& K.D. Hyde, sp. nov., are new to science and established with morphological and DNA sequence based evidence. All taxa collected are described and illustrated with coloured photographs. We present an updated phylogeny for Ganodermataceae based on nrLSU, ITS, nrSSU, TEF1 and RPB2 DNA sequence data and species relationships and classification are discussed.
\end{abstract}

Key words - new taxa - new records - morphology - pathogenic species - phylogeny 